\title{
A gravidade da imagem: arte e memória na contemporaneidadea
}

\author{
Adriano Carvalho Araújo e Sousa
}

COSTA, L. C.

A gravidade da imagem.

Rio de Janeiro: Quartet, 204 p., 2014.

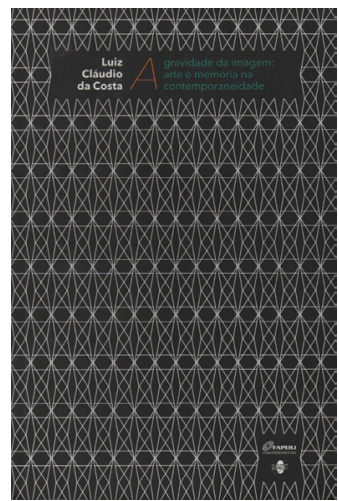

Resumo: A experiência contemporânea da comunicação, caracterizada por uma multiplicidade de imagens, convoca imediatamente a pensar o problema do arquivo em suas relações com a memória e o fotográfico no contexto da produção artística. Sobrevivências da imagem se oferecem da seguinte forma: quanto mais o fotográfico invade a arte, mais ela se torna gesto.

Palavras-chave: arquivo; memória; fotografia; arte.

Abstract: The gravity of image: art and memory in contemporaneity - The contemporary experience of communication with its multiple images invites us immediately to rethink the problem of archive in its relations to memory and the photography of a certain artistic creation. Survivals of the image are offered as follows: the more the photographic goes through the arts, the more it becomes gesture. It leads us to think "the conditions of giving themselves to the gaze" that provides certain artistic production without forgetting to investigate the place of the body.

Keywords: archive; memory; photography; body. 
Em A Gravidade da Imagem, Luiz Cláudio da Costa trata das relações entre arquivo e memória, a partir da análise de certa produção artística contemporânea. Nesse sentido, o título é feliz, como assinala o prefácio de Maurício Lissovsky, numa frase de grande força: "restituir às imagens, sua gravidade". A Quartet, com apoio da Faperj, leva a público uma edição simples, sem perder a elegância.

O livro divide-se em dois momentos. O primeiro situa um debate teórico, referente a questões como o arquivo, a memória e o fotográfico, em relação aos dispositivos. Considera transformações no plano epistemológico surgidas nos meados do século XX, quando eram repensadas noções advindas da teoria da linguagem. Remete a arquivo, memória, presença e ausência pensando alternativas à dicotomia "realismo da representação e idealismo da abstração" (COSTA, 2014, p. 47) e buscando nos artistas sobrevivências da imagem na contemporaneidade: quanto mais o fotográfico invade a arte, mais ela se torna gesto.

Nos termos do autor, estão em jogo as "condições de dar-se a olhar" que as obras proporcionam como uma visada contemporânea do lugar que o documento e o corpo ocupam, no sentido de se apresentarem como sobrevivências da imagem e do fotográfico, por exemplo, levando a aproximações com outros horizontes como a pintura, a land art, a performance, o cinema e as videoinstalações. O estatuto da memória é interrogado (junto com o dispositivo, dado fundamental para o campo da comunicação), sendo pensado como parte de uma época de transformação radical da nossa experiência e percepção de tempo determinado pelas novas mídias digitais: uma era em que tudo praticamente se tornou ou encontra seu equivalente na imagem.

No segundo momento, o leitor é convidado a apreciar leituras dos trabalhos, dentre as quais destaco entre outros, Rosângela Rennó, Alfredo Jaar e Doris Salcedo.

Há alguns anos, após uma sessão de Filme de Amor (2003), Júlio Bressane falou sobre uma "tradição de obscuridade" no cinema brasileiro, para referir-se ao acesso às películas e à sua conservação. Por sua vez, Luiz Cláudio, que é autor de ensaio sobre o cineasta, nos fala em "máquinas de esquecimento institucional" (Costa, 2014, p. 54) e mais adiante, ao analisar A01 [COD.19.1.1.43]-27[2|COD.23] e 2005-510117385 de Rosângela Rennó, debate a amnésia que, além de possibilitar o roubo de fotografias antigas, "permite o esquecimento e o apagamento voluntários da história" (Ibidem, p. 135). Rennó faz do álbum um objeto artístico e mostra a inoperância institucionalizada como norma, a violência de páginas em branco, versos de fotografias, vultos e sombras. Os furtos aos acervos bibliotecários têm a ver com a tradição de obscuridade que envolve as artes no Brasil. O autor nos recorda o incêndio trágico que destruiu 90\% das obras de Hélio Oiticica.

De Alfredo Jaar, chileno radicado em Nova York, o destaque recai sobre Os Olhos de Gutete Emerita. Luiz Cláudio explora os limites da linguagem do artista para expressar situações de violência extrema, caso de genocídios como o de Ruanda. Os Olhos de Gutete Emerita enfrentam a questão, se pensarmos que o silêncio normalmente é visto como uma figura de linguagem. Em sua análise, o autor oferece uma percepção ainda mais 
radical, porque parece ensinuar que desse acúmulo de escombros e ruínas da guerra talvez tenha restado apenas o silêncio como dobra ao infinito e vertigem. A nudez do olhar da sobrevivente e testemunha de uma catástrofe não se reduz ao silêncio, ela funda uma alteridade desconcertante: a "experiência indizível da memória do outro violado" (Ibidem, p. 157).

A colombiana Doris Salcedo, autora de Schibboleth, entre outras, transfigura uma experiência de extermínio, mas sem nostalgias. Luiz Cláudio se concentra em Noviembre 6 y 7. Convida o olhar à vertigem, à multiplicação de cadeiras em queda como "lembranças de ausências", possibilidade de evocação dos mortos nem que seja como distanciamento e opacidade. O autor destaca as cisões do tempo: "a obra convoca a imagem da queda associada a uma sociedade que convive há tantos anos com a guerra" (Ibidem, p. 176), "um fim que se repete a cada nova data, de modo que o presente não passa" (Ibidem, p. 178), para "não esquecer os mortos e fazer o luto impossível" (Ibidem, p. 180).

O autor interessa-se também pelo confronto dos artistas com os fantasmas do esquecimento e experiências traumáticas. A guerra vai se pulverizando e deixa pelo caminho "lacunas e silêncios", acumulando apenas "coleções de ausências". E qual o sentido desta Gravidade da Imagem? "A gravidade da imagem não remete a um fato histórico representado, mas à identificação afetiva com os sofrimentos de quem submergiu com a colonização" (Ibidem, p. 57).

Para nos evocar Derrida, Luiz Cláudio nos oferece mais que senhas para esses artistas, um schibboleth para ter o direito de passar e vislumbrar outros horizontes, em meio à paisagem de ruínas, à impossível repetição do evento, à experiência contemporânea.

Adriano Carvalho Araújo e Sousa é doutor em Comunicação e Semiótica pela PUC-SP e autor de Poética de Júlio Bressane: Cinema(s) da Transcriação.

logodedalo@hotmail.com 